\title{
Processo de ocupação dos Cariris Velhos - PB e efeitos na cobertura vegetal: contribuição à Biogeografia Cultural do semiárido
}

\author{
The ocupation process of the Cariri Velhos - PB and the effects in the vegetal cover: \\ contribution to the Cultural Biogeography of the semiarid
}

Bartolomeu Israel de Souza

Geógrafo, Prof. Dr. da Universidade Federal da Paraíba - UFPB

bartolomeuisrael@gmail.com

Ramon Santos Souza

Geógrafo, Mestrando do Programa de Pós-Graduação em Geografia da UFPB

ramonssouza93@gmail.com

\begin{abstract}
Resumo
A caatinga é uma formação vegetal que tem sido alterada de forma mais intensa a partir do período de colonização europeia no Brasil. O objetivo desse trabalho foi investigar como esse processo vem ocorrendo ao longo do tempo na região dos Cariris Velhos da Paraíba (Brasil) e quais as consequências resultantes. A metodologia utilizada foi baseada na análise de documentos históricos, trabalhos de campo e imagens de satélite, identificando as principais mudanças ocorridas até a fase atual. Os resultados encontrados indicam a ocorrência de transformações profundas na vegetação nativa, principalmente a partir da expansão do cultivo do algodão e da pecuária na região, com a caatinga diminuindo ao longo do tempo, tanto em quantidade como em diversidade, estabelecendo a criação de diversas áreas desertificadas, além de parte da vegetação nativa ter sido substituída por espécies exóticas, onde se destaca a algaroba (Prosopis juliflora) nas várzeas dos rios, existindo atualmente apenas poucos remanescentes mais preservados.
\end{abstract}

Palavras-chave: Caatinga, Cariri Paraibano, Uso dos Solos, Efeitos na vegetação.

\begin{abstract}
The caatinga is a vegetation formation that has been intensely modified since the european colonization of Brazil. The main goal of this project was investigating how this process has evolved trough time in the Cariris Velhos region of Paraíba (Brazil) and its consequences. The utilized methodology was based on the analysis of historical documents, field research and satellite images, identifying the main changes that took place until today's stage. The encountered results indicate the occurrence of deep transformations in caatinga's natural vegetation, especially after the expansion of cotton and cattle farming, with the shrinkage of caatinga's territory being a consequence, such as its diversity, resulting in the creation of countless desertified areas, in adition to part of the native vegetation being substituted by exotical species, with the algaroba (Prosopis juliflora) being a main treat, sprouting in river lea's, with only a few being preserved today.
\end{abstract}

Keywords: Caatinga, Cariri Paraibano, Land Use, Effects on vegetation. 


\section{INTRODUÇÃO}

Entendida a partir do século XIX como uma disciplina científica situada na interface entre a Geografia Física e Humana e tendo como tarefa investigar a distribuição dos seres vivos na superfície terrestre em diferentes escalas de espaço e tempo (FIGUEIRÓ, 2015), a Biogeografia representa um campo do saber para onde convergem diferentes setores de estudo que, ao serem tratados de forma integrada, desafiam o saber fragmentado, o que a torna uma área do conhecimento interdisciplinar por excelência.

Dividindo-se em dois grandes campos de pesquisa (Fitogeografia e Zoogeografia), a Biogeografia apresenta geralmente três grandes divisões onde esses campos são abordados: Histórica (Paleobiogeografia), fundamentando suas análises em processos evolutivos ao longo de grandes períodos geológicos; Ecológica, respaldada por mudanças ocorrentes em períodos e escalas espaciais mais curtas, estudando como os fatores ambientais atuais influenciam os seres vivos e como estes respondem a essas variações ecológicas; Cultural, onde temos a compreensão do papel do Homem na modificação da biota (FIGUEIRÓ, 2015).

No último caso citado anteriormente, temos o encontro mais perceptível de diversas áreas do conhecimento, como Biologia, Geografia, Sociologia, História e Economia, compartilhando não apenas a interação entre a Natureza e a Sociedade, mas principalmente a transformação mútua de ambos. Em termos espaciais, temos nas paisagens a expressão dos processos ecológicos e das práticas culturais. Em termos temporais temos a sobreposição do tempo profundo das espécies e o tempo histórico cultural das sociedades humanas. Trabalhar nessa perspectiva significa incorporar à funcionalidade biológica o inventário histórico da área estudada (FURLAN et al., 2016), o que significa atender a novas demandas sociais, onde temos uma natureza instrumentalizada, como se refere Santos (1997), e colaborar para uma renovação teórico-metodológica da Biogeografia desenvolvida por geógrafos, ainda fortemente influenciada por concepções clássicas da Biologia, onde temos o domínio do cartesianismo (ALBUQUERQUE et al., 2004).

A necessidade de considerar a ação humana nos estudos biogeográficos sob a perspectiva da Geografia exige, portanto, explicar a natureza incorporada ou recriada pelo Homem. De acordo com Albuquerque et al. (2004), esse processo vem ocorrendo em nível internacional desde a década de 1930, através dos trabalhos de De Martonne (1932), Font i Quer (1954), Elhai (1968), Quintanilla (1981), Meaza (1993), García Fernandez (2001) e Velasco (2001), entre outros. No Brasil, essa perspectiva é discutida mais recentemente no trabalho de Furlan et al. (2016), como resultado de uma análise da produção científica apresentada no XI Encontro Nacional da ANPEGE de 2015, onde pela primeira vez esse evento incorporou um eixo de discussões com o título "Biogeografia e Geoecologia da Paisagem". 
Em se tratando da cobertura vegetal, para além da Geografia, essa perspectiva também é defendida por pesquisadores de outras áreas, como a Antropologia, a exemplo de McNeely (1994), para quem a humanidade tem sido uma força dominante na evolução das florestas de hoje, gerando modificações que tanto podem atingir níveis elevados de degradação como efetuar transformações que se caracterizam pelo retorno a um estado altamente produtivo e diversificado.

Destacamos que, para além da superação de questões de ordem teórica e epistemológica, a perspectiva acima mencionada também incorpora dificuldades técnicas para análise dos processos ocorrentes, a exemplo da sua reprodução espacial através do mapeamento dos processos envolvidos, uma vez que o desenvolvimento de uma cartografia capaz de traduzir adequadamente fenômenos cada vez mais dinâmicos ainda não foi respondida de forma satisfatória e se coloca como um dos maiores desafios a serem superados pela Ciência da Geoinformação, onde são desenvolvidas as representações computacionais do espaço.

Sobre a área onde foi desenvolvido esse trabalho, esta compreende grande parte da região dos Cariris Velhos (ou Cariri), onde estão o Alto Curso do Rio Paraíba e a Área de Proteção Ambiental do Cariri, unidade de conservação de elevada importância biológica para o bioma caatinga (Figura 01), num eixo que se distancia de 180 a pouco mais de $300 \mathrm{~km}$ de João Pessoa (capital da Paraíba), perfazendo um vasto território que recobre quase $20 \%$ do estado em questão.

Os elementos comuns do conjunto de paisagens existentes nessa região são os baixos índices pluviométricos (cerca de 500mm anuais), tidos como os menores do país, as temperaturas médias elevadas (cerca de $27^{\circ} \mathrm{C}$ ), altitudes médias dominantes de 500 metros (ainda que variem entre 400 a pouco mais de 1.000 metros), caatinga hiperxerófila, as limitações edáficas (solos rasos e, em muitos casos, com altos teores de salinidade), cidades pequenas, baixa densidade demográfica e altos níveis de degradação da cobertura vegetal convivendo com áreas pontuais onde temos importantes remanescentes de uma caatinga densa e florestal (SOUZA, 2008).

O objetivo desse trabalho foi analisar o processo de ocupação histórica dessa região e as suas consequências no estabelecimento das paisagens atualmente existentes, particularmente no que diz respeito aos efeitos na cobertura vegetal, exposto através de uma discussão sobre as espécies que regrediram e se expandiram, além de um mapeamento representando essa dinâmica, desde o processo de colonização dessas terras aos dias atuais. 

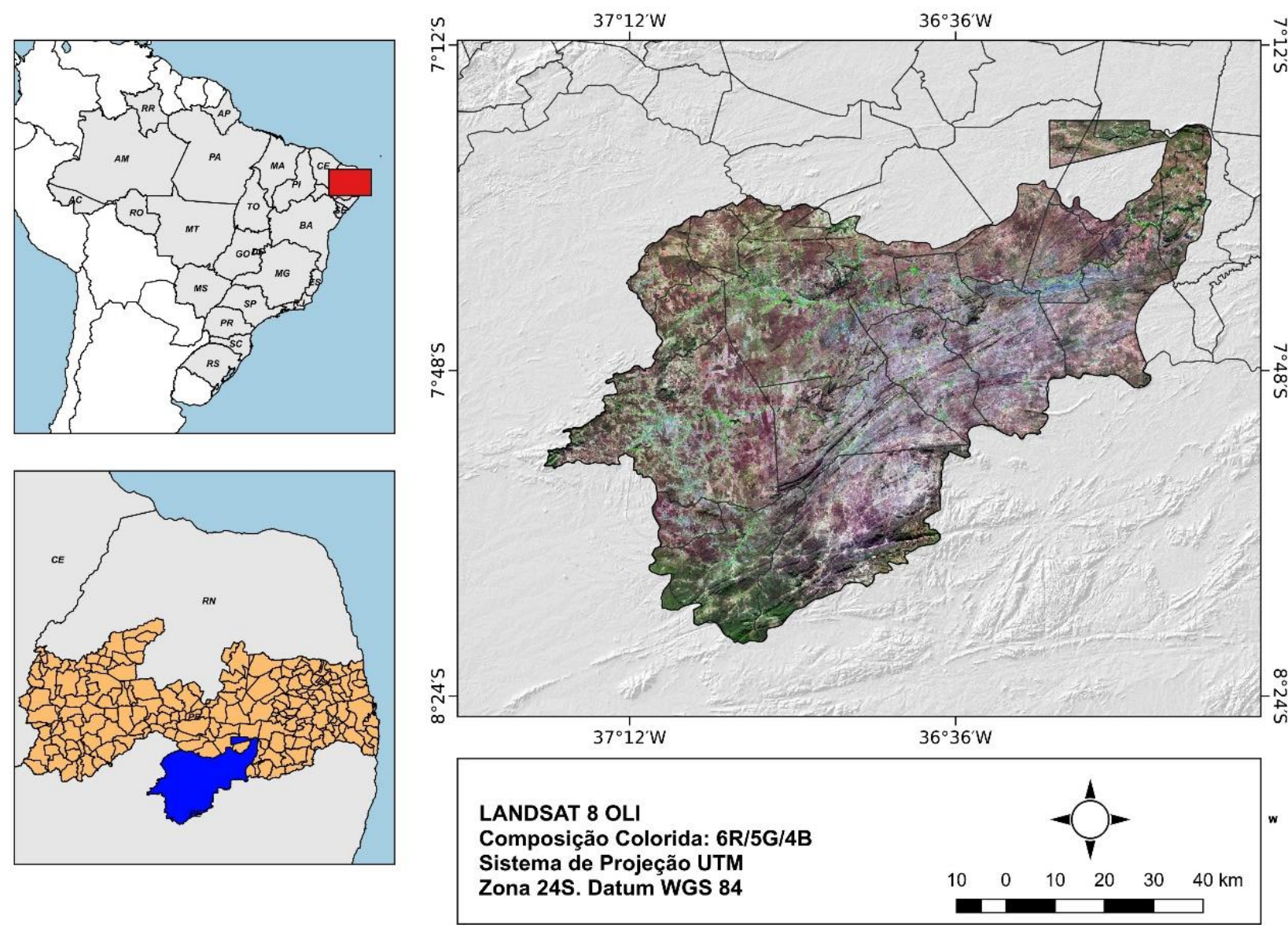

Composição Colorida: 6R/5G/4B

Sistema de Projeção UTM

Figura 1 - Localização do Alto Curso do rio Paraíba (área maior da figura) e da APA do Cariri (área retangular da figura).

Fonte: Elaborado pelos autores.

\section{PROCEDIMENTOS METODOLÓGICOS}

Os procedimentos utilizados para sintetizar os processos de transformação da paisagem da Sub-bacia do Alto Curso do Rio Paraíba consistiram na pesquisa documental, realização de trabalhos de campo e entrevistas semiestruturadas, elaboração e interpretação de mapas, expressos na figura 2, a seguir.

A pesquisa documental consistiu na consulta a diversos trabalhos que relatam situações de uso dos solos e os impactos ocorrentes na vegetação de caatinga, tanto de forma geral como para a região estudada, desde o século XVII aos dias atuais (AGUIAR; RIBEIRO COUTINHO, 1982; ALMEIDA, 1979; 1994; ANDRADE, 1997; ARRUDA MELLO, 2002; COHEN, 1997; FERREIRA， 1993; GRABOIS; AGUIAR, 1984; JOFFILY， 1892; 1910; LEAL， 1993; LUETZEUBURG, 1922; MELLO NETO, 1982; MOREIRA; TARGINO, 1995; NANTES, 1979; PINTO, 1977; XAVIER, 1942). Estes documentos constituem-se em importante fonte de informação na perspectiva da Biogeografia Cultural, devido a riqueza em descrição das paisagens percorridas, muitas vezes acompanhadas de relatos sobre alguns aspectos culturais e econômicos da 
região e da ligação das mesmas com outras partes do país e do mundo, ajudando a compreender as razões pelas quais os usos dos solos foram efetuados daquela forma.

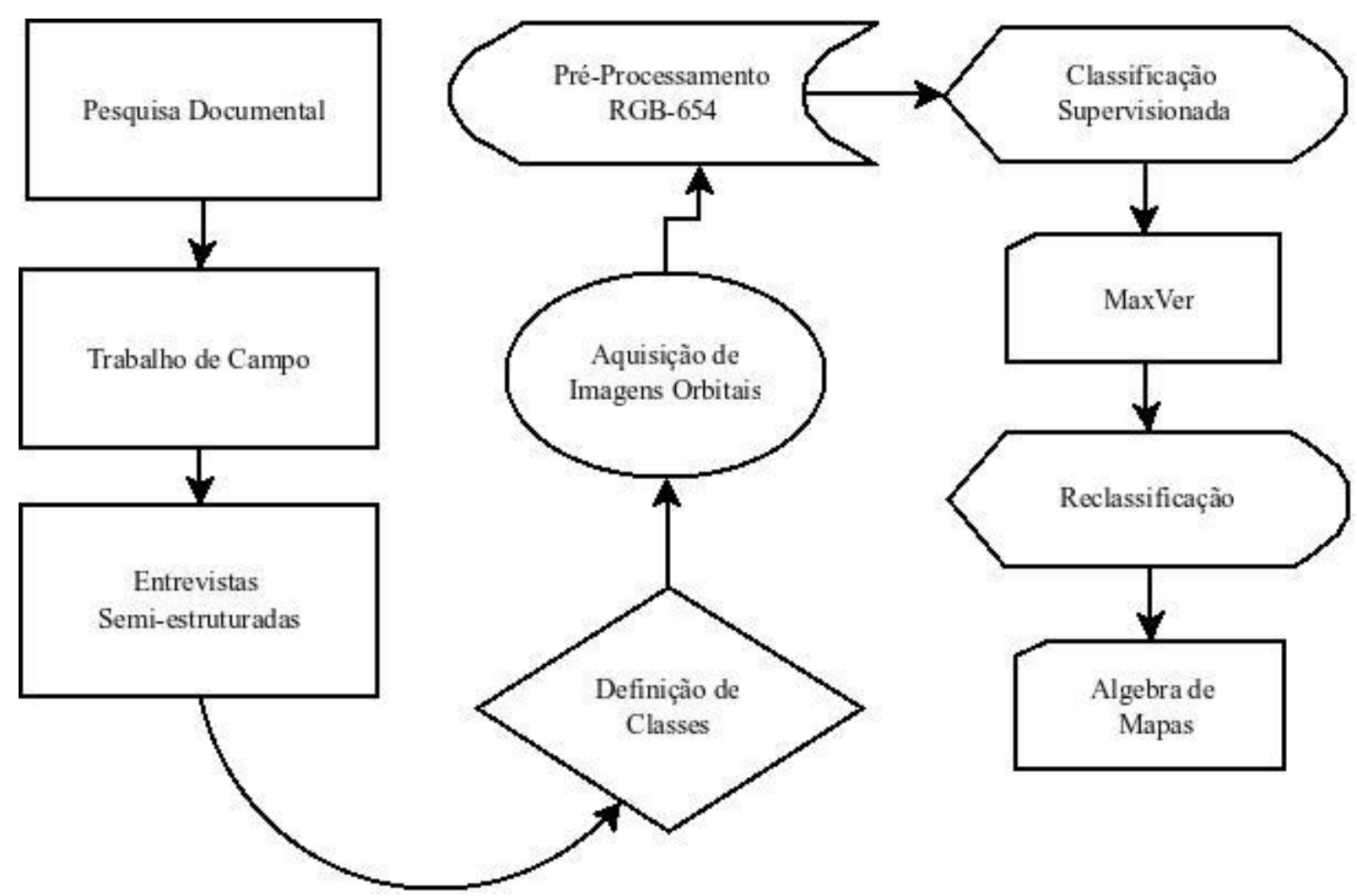

Figura 2 - Fluxograma com os procedimentos técnicos utilizados no desenvolvimento do trabalho.

Os trabalhos de campo foram efetuados para observar a dinâmica recente no uso e ocupação das terras do Cariri e fornecer informações mais detalhadas a respeito da vegetação, sua diversidade e interação com aspectos da geomorfologia, hidrologia, tipos de solos e seus usos atuais. Para esse último caso, têm sido efetuados levantamentos de vegetação na região desde o ano 2011, cujos resultados foram divulgados de forma mais detalhada em Souza et al. (2015a e 2015b). O procedimento utilizado nesses levantamentos está baseado na proposta biogeográfica de Cámara e Díaz del Olmo (2004), a qual consiste no estabelecimento de um censo de plantas lenhosas arbustivas e arbóreas existente em um trecho linear de 50 metros de largura e 2 metros de comprimento delimitados por uma fita métrica, perfazendo uma área de 0,1 hectares onde são identificados e medidos os indivíduos existentes. Até o momento já temos um banco de dados com informações de cerca de 2 hectares da região. Para o desenvolvimento desse trabalho, foram utilizadas informações relativas a identificação das espécies e os estratos que estas ocupavam, em condições de conservação e degradação, comparando com o que os documentos históricos 
relatavam sobre áreas em situações geomorfológicas e pedológicas similares, afim de tentar recompor a dinâmica ocorrida ao longo do tempo em função do uso dessas terras.

Ainda como parte dessa fase de campo, foram efetuadas entrevistas semiestruturadas com pessoas a partir dos 70 anos, moradoras da região, para identificarmos através da história oral como se processou a partir do século XX a ocupação das terras dessa região e os efeitos na cobertura vegetal.

Sobre essa fase, entendemos que a pesquisa de campo é um “...instrumento de análise geográfica que permite o reconhecimento do objeto e que, fazendo parte de um método de investigação, permite a inserção do pesquisador no movimento da sociedade como um todo..." (SUERTEGARAY, 2002, p. 4), sendo fundamental para reconhecer na prática a dinâmica da natureza e a sua articulação com a sociedade. Portanto corresponde a uma etapa fundamental para o desenvolvimento da investigação, fornecendo informações insubstituíveis para que haja uma melhor interpretação do que está sendo observado a partir, por exemplo, do uso de técnicas de Sensoriamento Remoto, antes, durante e depois destas.

Quanto as técnicas de Sensoriamento Remoto para uma análise de dinâmicas mais recentes na região, foram utilizadas imagens de satélite provenientes do Landsat-8, sensor OLI (Operational Land Imager), órbita 215, cenas 65 e 66, disponibilizada pela USGS, sensores com bandas multiespectrais e resolução espacial de $30 \mathrm{~m}$. A data de passagem do satélite foi 12-08-2016, escolhido pelo fato de apresentar imagens limpas de nuvens e ainda com presença de cobertura foliar em diversas espécies da caatinga.

A classificação das imagens para a geração dos mapas de uso e cobertura da área de estudo foi tratada e manipulada no plugin Semi-Automatic Classification Plugin-SCP do QGIS versão 2.16x, através de treinamento supervisionado, com classificador Máxima Verossimilhança, limiar de aceitação de $100 \%$. Os elementos presentes nas imagens foram identificados e associados utilizando-se a composição 6R/5G/4B para o sensor OLI do Landsat-8. No plugin também foi possível a elaboração da matriz de transição.

As classes de uso dos solos foram definidas a partir da pesquisa efetuada nos documentos históricos, nos trabalhos de campo e através das informações geradas pelo trabalho de tese de Souza (2008) na região. Dessa forma, foram construídos três cenários cartográficos que associam os elementos analisados, sintetizando as informações destacadas e fazendo com que haja uma melhor visualização desses processos ao longo do tempo e do espaço. Tais procedimentos foram efetivados a partir da reclassificação das imagens de satélite. 


\section{RESULTADOS E DISCUSSÕES}

Para efeitos de classificação e mapeamento dos diferentes tipos de caatinga presentes no Cariri, consideramos o fato de que, ainda que exista uma nomenclatura utilizada oficialmente para esse tipo de vegetação (Savana Estépica), dividida em quatro subgrupos (Florestada, Arborizada, Parque e Gramíneo-Lenhosas) pelo IBGE (1991), da mesma forma que outras classificações existentes anteriormente, os trabalhos que até o momento se propuseram a realizar essa tarefa não foram capazes de contemplar, satisfatoriamente, toda a sua fitofisionomia e estrutura (ANDRADELIMA, 1981; BERNARDES, 1999; ANDRADE et al., 2005).

Diante dessa situação, ao consultarmos algumas das classificações propostas para a caatinga (RIZZINI, 1963; EITEN, 1974 e 1983; ANDRADE-LIMA, 1981; VELOSO; GÓES-FILHO, 1982), optamos por estabelecer uma classificação própria, baseada na associação de diversas características dos autores citados e das nossas observações e práticas de campo.

Dessa forma, para o reconhecimento dos tipos de caatinga existentes no Cariri, estabelecemos a seguinte classificação:

1) Caatinga Arbórea - Localizada predominantemente nas várzeas dos rios, zonas serranas e no entorno de alguns afloramentos rochosos mais expressivos (lajedos), onde temos maior umidade e solos mais profundos (Neossolo Flúvico, Neossolo Regolítico e Argissolo vermelho - amarelo)). As espécies dominantes originalmente são a aroeira (Myracroduon urundeuva), a baraúna (Schinopsis brasiliensis), o pau-ferro (Caesalpinia férrea, var. Leiostachia), o jatobá (Hymenaea rubriflora), o mulungu (Erythrina velutina), o juazeiro (Zizyphus joazeiro), a craibeira (Tabebuia aurea), o tamboril (Enterolobium contortisiliquum), a oiticica (Licania rigida), a quixabeira (Sideoxylun obtusifolium) e o ipê - roxo (Handroantus impetiginosus).

2) Caatinga Arbóreo-Arbustiva Fechada: Localizada próxima às várzeas, em solos relativamente profundos (Neossolo Regolítico) e nas áreas serranas. Representam uma fitofisionomia com presença de menos umidade nos solos que a anterior. $\mathrm{O}$ uso dessas áreas para pastejo ou qualquer outra atividade econômica era pequeno, o que, associado a presença de elementos naturais mais favoráveis (solos, umidade e temperaturas menos elevadas nas zonas serranas), lhes conferia elevada diversidade vegetal, com predomínio do estrato arbóreo e secundariamente do estrato arbustivo. Nesse caso, ocorreria a dominância de espécies onde sobressaiam o angico (Anadenanthera colubrina), a imburana-de-cheiro (Amburana cearensis), a imburana de cambão (Commiphora leptophloeos), a catingueira (Poincianella gardneriana), o umbuzeiro (Spondias tuberosa), o pereiro (Aspidosperma pyrifolium), o facheiro (Pilosocereus pachycladus), o mandacaru (Cereus jamacaru), a imbiratanha (Pseudobombax marginatum), o pau - ferro (Caesalpinia ferrea, var. férrea), o catolé (Syagrus cearenses), o pau de serrote (Luetzelburgia auriculata), icó (Capparis icó) e a barriguda (Ceiba glaziovii). As espécies arbustivas dominantes seriam o pinhão-bravo (Jatropha molissima), o marmeleiro (Croton blanchatinus), a jurema-preta (Mimosa tenuiflora), a jurema branca (Piptadenia stipulacea), o pacotê (Cochlospermun vitifolium), o bom nome (Maytenus rígida), a maniçoba (Manihot glaziovii), o xique-xique (Cereus gounellei) e a palmatória-de-espinho (Opuntia palmadora). No estrato herbáceo dominariam 
a macambira (Bromélia laciniosa), o caroá (Neoglaziovia variegata), a coroa-de-frade (Melocactus bahiensis), a palmatória-de-pêlo (Opuntia inamoena), a jureminha (Desmanthus virgatus), o velame (Croton campestris), a malva-branca (Sida galheirensis), a macambira (Bromélia laciniosa) e, durante a estação chuvosa, principalmente o capimpanasco (Aristida adscensionis).

3) Arbustivo-Arbórea Fechada: Ocorrência das mesmas espécies da classificação anterior, embora com estrato arbustivo dominante sobre o arbóreo, o que reflete a presença de solos menos profundos (Luvissolo Crômico e Neossolo Litólico) e, em certas áreas, com problema de drenagem e salinidade (Vertissolo e Planossolo Háplico), além de maior presença de antropismo, através da retirada de algumas espécies arbóreas e do pastoreio, quando comparada à classificação anterior. Pode-se dizer que seria uma caatinga secundária, em avançado estágio sucessional.

As classificações anteriores corresponderiam aos tipos de caatinga florestal e as espécies vegetais originalmente mais dominantes nessa região, com pouca influência antrópica. As classificações a seguir representam uma fase de maior intervenção humana, onde temos inclusive, em muitos setores, áreas desertificadas, dada a rarefação de cobertura vegetal e a dificuldade para que haja uma recomposição espontânea de diversas espécies ao longo do tempo. Por outro lado, também podem representar áreas dessa região que apresentam alguns elementos naturais que dificultam o domínio do estrato arbóreo e de maior adensamento vegetal, a exemplo de solos com problemas de salinidade, como o Planossolo Nátrico, ainda que as atividades humanas estejam piorando a situação encontrada.

4) Caatinga Arbustiva Fechada: Localizadas em áreas distantes da várzea, onde predominam solos rasos e com pequena capacidade armazenamento de água (Luvissolo Crômico e Neossolo Litólico). As plantas existentes nessas áreas não chegam a compor estrato arbóreo, uma vez que as espécies correspondentes a essa classificação encontram-se muito dispersas, havendo o domínio de arbustos e herbáceas. Apesar das manchas de solo exposto estarem mais presentes que nos subtipos anteriores, ainda predomina a presença de forte cobertura vegetal. Esta pode ser caracterizada como uma área onde a sucessão ecológica está em fase intermediária e, caso diminuísse o uso dessas terras pela pecuária e retirada da madeira, poderia evoluir para um estágio mais avançado. Apesar da presença de alguns elementos arbóreos, onde se destacam o pereiro (Aspidosperma pyrifolium), a catingueira (Poincianella gardneriana) e o facheiro (Pilosocereus pachycladus), as espécies de maior dominância são as arbustivas pioneiras, onde o pinhão-bravo (Jatropha molissima), o marmeleiro (Croton blanchatianus), o mofumbo (Combretum leprosum) e a jurema-preta (Mimosa tenuiflora) recobrem extensas áreas, formando elevado adensamento, o mesmo ocorrendo com o xiquexique (Cereus gounellei), cactácea de maior presença nesses terrenos, enquanto as espécies herbáceas são as mesmas encontradas noutras áreas.

5) Arbustiva Semiaberta e Aberta: Apresenta estágio avançado de degradação, onde grandes manchas de solo recobertas apenas por plantas herbáceas dividem espaço com pequenas ilhas de vegetação. Nessas áreas, destacam-se pela sua maior presença o pereiro (Aspidosperma pyrifolium) e a catingueira (Poincianella gardneriana), ocorrendo também o pinhão-bravo (Jatropha molissima) e o xique-xique (Cereus gounellei). Devido ao tipo de 
madeira, estas espécies raramente são utilizadas para a produção de lenha ou carvão, apresentando também pouco ou nenhum uso na construção de cercas, o que as livra de um uso mais intensivo. Além disso, no caso do pereiro (Aspidosperma pyrifolium), ainda que a sua presença seja registrada em todos os tipos de caatingas existentes, onde ocorre a presença de solos argilosos de alta atividade coloidal, com PH de neutro á alcalino e teores altos de nutrientes (AMORIM et al., 2005), o seu elevado número nessas áreas também está relacionado ao fato das suas folhas serem tóxicas quando verdes, o que faz com que o gado geralmente se utilize somente das folhas secas caídas no chão, quando perdem a toxicidade. Nesse sentido, a espécie não é pressionada pela pecuária. Em relação a catingueira (Poincianella gardneriana), esta se caracteriza pelo aumento de rebrota quando as terras onde ela está presente são submetidas às queimadas (SAMPAIO; SALCEDO, 1993), possuindo também elevada resistência à seca e capacidade de competição por luz (SAMPAIO et al., 1998). Além dos aspectos mencionados, estas duas espécies apresentam outra característica que explica a sua dominância nos diversos tipos de caatinga e, particularmente, nas áreas mais degradadas, ou seja, picos de floração que podem ocorrer na estação seca e/ou chuvosa (BARBOSA et al., 1989), o que torna mais intensa a sua dispersão pelos agentes polinizadores. Quanto ao estrato herbáceo, dominam abundantemente a malva-branca (Sida galheirensis) e o velame (Croton campestris), indicadoras de uma sucessão secundária regressiva, já que as suas populações tendem a aumentar com a intensificação do processo de degradação (ARAÚJO FILHO; CARVALHO, 1997), além do capim panasco (Aristida adscensionis).

Nessa região também existem alguns Brejos de Altitude, em áreas à barlavento das massas úmidas, particularmente na fronteira com o estado de Pernambuco, onde temos remanescentes florestais com espécie de Mata Atlântica. Nesse trabalho essas áreas não serão abordadas, uma vez que até o momento não foram efetuados levantamentos de vegetação suficientes para uma boa caracterização fitossociológica.

Para melhorar o entendimento sobre o uso e ocupação dessas terras e os efeitos na cobertura vegetal ao longo do tempo, dividimos os resultados e análises em três momentos: início da colonização, domínio da cotonicultura e fase atual.

\subsection{Início da colonização:}

Foi somente a partir de 1663, como registram as concessões das primeiras sesmarias, que a região do Cariri começou a ser colonizada e explorada economicamente. Foi pioneiro Antônio de Oliveira Lêdo, originário de Pernambuco, que requereu 30 léguas de terras ao longo do rio Paraíba, fazenda essa estabelecida no lugar que deu origem a cidade de Boqueirão (ALMEIDA, 1979).

Nesse contexto, é feita a primeira descrição sobre o Cariri e as características da vegetação de parte dessa região, através do padre Martinho de Nantes, numa viagem de volta da missão indígena localizada na cidade atual de Boqueirão para o estado de Pernambuco, executada em 1670, quando essas terras ainda eram quase inexploradas por mãos européias: 
Fiquei somente oito meses nessa aldeia; porque, tendo sabido que havia muitas aldeias de cariris no rio S. Francisco, resolvi para lá seguir; por essa razão, voltei a Pernambuco com quase tanto trabalho quanto o que havia suportado na ida para a missão, debaixo de chuva desde o dia de nossa partida até proximidades de Pernambuco, já perto da quaresma. Pensei perder-me numa floresta que tem doze a catorze léguas de percurso, distanciado dos índios por minha inadvertência. Quando o percebi, eles estavam longe, tendo tomado outro caminho. Foi com dificuldade que eles me ouviram, quando gritei várias vezes a plenos pulmões. (NANTES, 1979, p. 33).

Pela descrição apresentada, fica claro que a vegetação encontrada nesse trecho do Cariri deveria ser, além de extensa, fechada e de porte arbóreo, como ainda hoje se observa em algumas áreas mais preservadas próximas à fronteira da Paraíba com Pernambuco.

Tendo a maior parte das tribos indígenas dessas terras, juntas com outras do Sertão, não se submetido a presença e domínio do colonizador branco, estas se organizaram no que foi denominado de Confederação dos Cariris ou Guerra dos Bárbaros, sendo esse conflito solucionado somente no início do século XVIII, através do extermínio e/ou expulsão desses nativos, o que ampliou a área a ser ocupada pela pecuária bovina, primeiro produto comercial do semiárido.

Através da expansão da pecuária extensiva, começaram também as modificações maiores nos padrões de caatinga do Cariri e, como regra, em toda a zona semiárida paraibana e nordestina, não apenas pelo consumo direto da vegetação nativa, mas também pelas constantes queimadas a que eram submetidas, cujo objetivo era a renovação do pasto durante o período chuvoso. Além disso, e em quantidades cada vez maiores, à medida que a população aumentava, era necessária a exploração de madeira para produzir carvão, lenha, cercas e material de construção para as moradias.

As áreas próximas às várzeas dos rios passaram ainda mais a ser exploradas nesse processo de expansão da ocupação inicial, o que pode ser explicado pela presença de água no lençol freático, mesmo durante o período de estiagem. As grandes distâncias e as dificuldades de comunicação em relação ao litoral, por sua vez, fizeram com que nas várzeas fossem desenvolvidas lavouras de ciclo vegetativo curto (particularmente o feijão e o milho), utilizadas para subsistência.

Nas áreas de entorno imediato das sedes das fazendas, a caatinga passava por um processo de rebaixamento e raleamento, feito com machado e queimadas, para evitar a presença próxima de animais peçonhentos, e também pelo seu uso contínuo como pasto nativo, o que lhe valeu o nome indígena de capoeira (mata que foi), ainda hoje utilizado em todo o Cariri paraibano e, por extensão, também no Sertão nordestino.

Quanto a pecuária, desde o início dessa ocupação, os bovinos eram criados soltos no pasto nativo (salvo as fêmeas em lactação, que ficavam presas no curral). Durante a estiagem, recebiam complemento forrageiro na área de pastagem, advindo este da sobra das culturas alimentares e 
também do algodão (restolho). Nesse caso, a agricultura sempre cumpriu um papel importante na economia de todo o Sertão nordestino, embora fosse uma atividade complementar à pecuária.

Os ovinos e principalmente os caprinos, por sua vez, também pastavam nessas áreas embora, devido a sua maior rusticidade e também por serem considerados um tipo de criação inferior aos bovinos, não tivessem acesso, em nenhuma época do ano, a nenhum complemento alimentar.

Além do etnocídio e do genocídio pelo qual passaram os indígenas, outro fator que contribuiu de forma marcante para a expansão da pecuária extensiva no início do século XVIII no Cariri, foi a resolução de uma Carta Régia do governo português, em 1701, determinando que a área de criação de gado, antes também feita no litoral, passasse a ocorrer na distância mínima de 10 léguas (cerca de $60 \mathrm{~km}$ ) da costa.

A criação dessa lei está baseada no fato de, nessa época, estar havendo uma maior procura de carne bovina por parte dos engenhos de cana-de-açúcar e dos centros urbanos em expansão. Além disso, a crescente atividade canavieira requeria um número cada maior de animais de tiro, o que resultava em conflitos de interesse constantes entre criadores e lavradores na Zona da Mata (MOREIRA; TARGINO, 1997).

Dentre as diversas ações empreendidas pelos primeiros colonizadores europeus no Cariri, tivemos a presença das queimadas, ainda hoje marcantes na região, utilizada principalmente como suporte da agricultura. Originalmente essa prática fazia parte de um conjunto de técnicas realizadas pelos índios antes da chegada dos colonizadores europeus, também com o objetivo principal de fazer roças de subsistência. Entretanto, devido ao pequeno tamanho das terras afetadas por essa intervenção, estas não chegavam a ser comprometidas seriamente, diferindo substancialmente do que passou a ser feito pelos colonizadores.

Esse conjunto de técnicas consistia na limpeza da terra a ser aproveitada, retirando-se todo vestígio de vegetação nativa (broca), concentrando-a em montículos e queimando-a (coivara). Tal processo adicionava ao solo alguns elementos orgânicos e minerais, anteriormente presentes na vegetação que, em princípio, elevavam a sua fertilidade.

Entretanto, em muitos casos, a repetição ininterrupta dessas técnicas na mesma área, terminava por sujeitar os solos a uma degradação elevada. Mesmo no caso de abandono da atividade agrícola, a regeneração natural da vegetação nessas áreas encontrava grandes dificuldades para se estabelecer, uma vez que a rebrota de diversas espécies da caatinga, tipo de dispersão comumente existente em grande parte desse ambiente, havia sido eliminada (PEGADO, 2004), o que ainda hoje é observado em diversas áreas do semiárido brasileiro.

Retornando às declarações do padre Martinho de Nantes expostas anteriormente, acreditamos que os colonizadores europeus, para longe de se depararem com um quadro homogêneo de cobertura vegetal, mesmo no período inicial da colonização do Cariri, se 
defrontaram com um conjunto de paisagens onde a caatinga era naturalmente bastante heterogêneo, o que pode ser comprovado ao analisarmos os relatos presentes em alguns documentos históricos referentes ao município de São João do Cariri. Sua sede, fundada em 1750, é o mais antigo núcleo urbano do interior da Paraíba. No ano anteriormente citado, o Monsenhor Pizarro deixou a seguinte descrição quanto a sua localização (LEAL, 1993, p. 54-55):

Sobre uma colina rodeada de outras semelhantes e pedregosas, cujo território árido e seco, e muito ventoso, ficando sobranceiro na margem esquerda do rio S. João, uma das cabeceiras do rio Paraíba, oferece soberba vista do anfiteatro, pelas diversas colinas e as serras que se seguem...Todo este país é conhecido por muito mimoso e próprio para criar gado, o que consiste o seu negócio principal.

A referência feita ao mimoso (Paspalum convexum) diz respeito a um tipo de gramínea nativa da caatinga, ainda hoje muito utilizada como pastagem pelo gado da região. Nesse caso, a menção a abundância dessa planta nos faz concluir que em algumas áreas do Cariri, tal como no entorno de São João do Cariri, seria comum e natural a presença de solos com pouca vegetação do tipo arbórea, mesmo considerando que a ocorrência de queimadas para criação de novos pastos e a provável expansão do cultivo do algodão pudesse estar piorando essa situação.

Também digno de referência é um ofício escrito em 1790 ao governador de Pernambuco (a quem na época a Paraíba estava submetida), por observadores do mesmo na cidade de São João do Cariri (antiga freguesia de Nossa Senhora dos Milagres). A função dos enviados do governador era observar a melhor localidade para a criação de um núcleo urbano maior, a Vila da Rainha, fato esse que originou uma disputa por tal investimento envolvendo São João do Cariri e a atual cidade de Campina Grande. O parecer dessas pessoas foi de que, na região em torno da primeira cidade, além da dificuldade de se produzir alimento suficiente para um núcleo urbano maior, ocorreria o seguinte aspecto negativo:

[...] se não acha em toda freguesia um só pau que possa servir para armar uma casa para qualquer que quiser morar, e sendo assim, como na verdade é, nunca poderia ter aumento a vila sendo erigida no lugar do Julgado; o que com muita suavidade se pode aumentar no lugar da Campina Grande em breve tempo e com menos despesas dos povos. (ALMEIDA, 1979, p. 46).

Na realidade, já em 1788 o Ouvidor Geral da Comarca da Paraíba recomendava a criação da Vila da Rainha em Campina Grande, alegando como razões que, em São João do Cariri, o terreno era muito seco e não admitia plantações, mas somente criação de gado. Em Campina Grande, por sua vez, a situação era bastante superior para investimentos do porte pretendido (PINTO, 1977). Pelo que foi exposto, não se descarta a possibilidade de que a carência em madeira em algumas 
áreas do Cariri, já nesse momento, fosse resultante de processos naturais, embora tenha sido intensificada pelas atividades humana com o passar do tempo.

Resumindo o que foi anteriormente descrito, a partir da segunda metade do século XVII, tendo iniciado o processo de colonização na região, alguns padrões originais de caatinga nessas terras começaram a ser modificados. Nesse contexto, verifica-se uma substituição parcial da Caatinga Arbórea existente, principalmente nas várzeas (Neossolo Flúvico), pela agricultura de subsistência, também seguida da retração da Caatinga Arbóreo-arbustiva Fechada das áreas mais próximas a esses primeiros tipos de solos. Na seqüência, ocorre uma expansão da Caatinga Arbustiva Fechada, substituindo parcialmente a vegetação Arbustivo-arbórea Fechada, devido a introdução do gado e o uso dessas áreas como pasto nativo, associadas as queimadas e a retirada da vegetação de porte arbóreo para diversos fins. Nas terras mais distantes dos cursos d’água e de maior elevação topográfica, a caatinga permaneceu na sua constituição original, mantendo as características da fase anterior a colonização. A materialização cartográfica desse momento pode ser observada na figura 3 , a seguir.

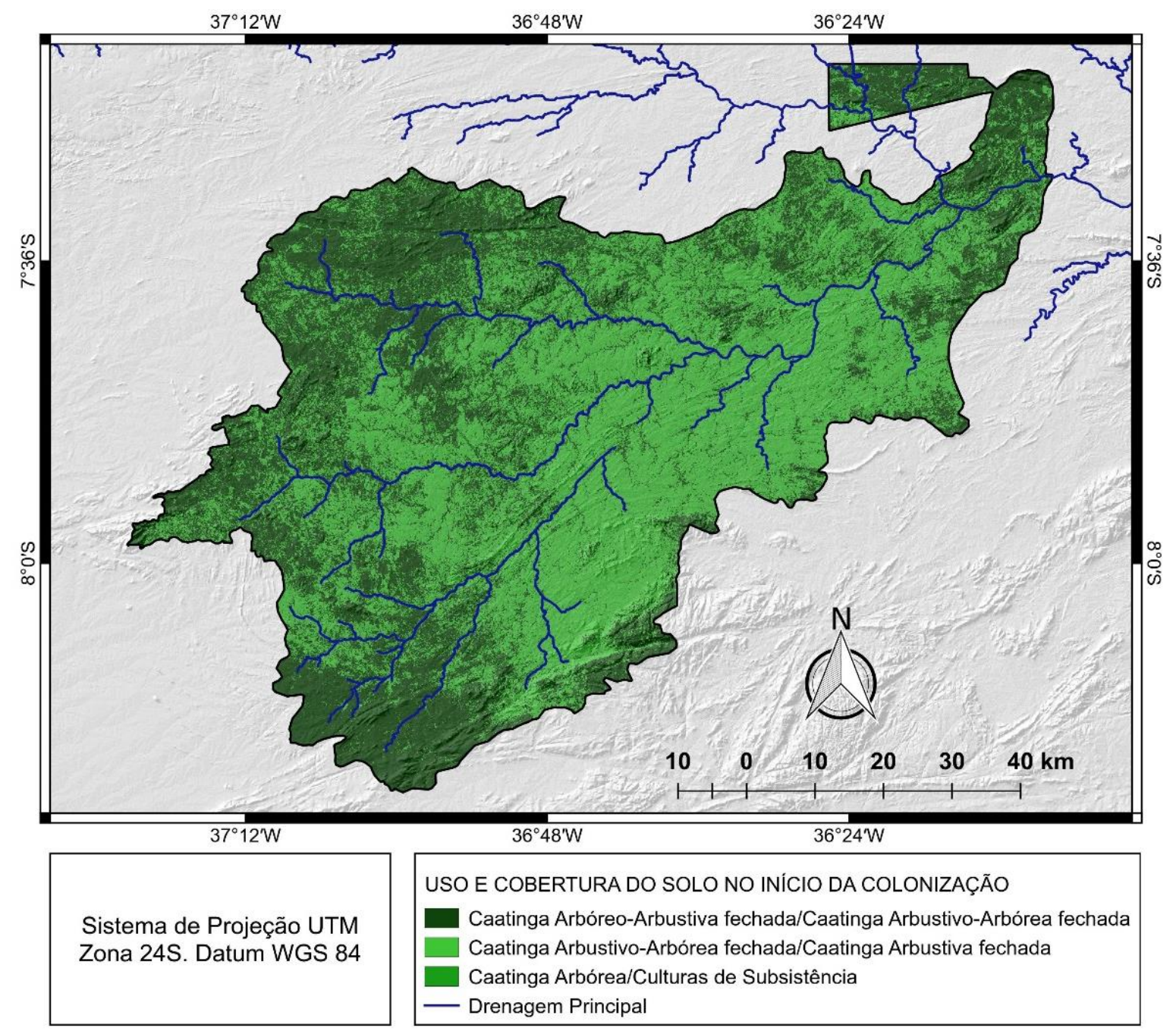

Figura 3- Mapa do uso e cobertura dos solos no Cariri, no início da colonização, a partir da segunda Metade do século XVII. 
Essas modificações foram efetuadas, em princípio, na Caatinga Arbórea (particularmente a Mata Ciliar) e na Caatinga Arbóreo-arbustiva Fechada em razão destas ocuparem as terras melhor providas de reservas de água ou mais próximas a estas, elemento de importância ainda mais vital num clima semiárido. Logo, em diversas áreas antes ocupadas por esses tipos de vegetação, começaram a ser introduzidos o gado, a agricultura de subsistência, a sede das fazendas e diversos empreendimentos a elas relacionados (cercas, currais, etc.), o que implicou no consumo e alteração de muitos padrões originais da cobertura vegetal original.

Com a expulsão, eliminação ou pacificação gradativa dos índios dessa região, ocorre a intensificação do estabelecimento de mais colonos no Cariri. Dessa forma, a pecuária se expandiu ainda mais, modificando assim a freqüência de uma série de espécies existentes, particularmente as de porte arbóreo, na Caatinga Arbustivo-arbórea Fechada, Arbustiva Fechada e Arbustiva Semiaberta e Aberta, enquanto o uso das áreas ocupadas originalmente pela Caatinga Arbórea (Mata Ciliar) e Caatinga Arbóreo-arbustiva Fechada foi ampliado, substituídas, com maior intensidade, pelas lavouras de subsistência, como o milho e o feijão que, mesmo sendo cultivados somente na estação chuvosa, exigem que o terreno esteja livre de árvores e arbustos, o que é feito ainda hoje nessa região e em grande parte do semiárido brasileiro.

Com o aumento da população, temos a ampliação do uso da vegetação como alimento para o gado, mas também, para além desse fim, tivemos a intensificação do consumo de diversas madeiras para as quais, dependendo para que finalidade fosse utilizada, haveria a preferência de determinadas espécies, levando em consideração a sua durabilidade, resistência, entre outras características. Nesse caso, observamos um largo uso doméstico e nas propriedades para diversas espécies, dentre as quais destacamos: craibeira (Tabebuia aurea) - porteiras dos currais, moirões das cercas, linhas dos tetos das casas, portas e janelas; baraúna (Schinopsis brasiliensis) - pisos das casas da população mais abastada, moirões da cercas; pereiro (Aspidosperma pyrifolium) - caibros dos tetos das casas; facheiro (Pilosocereus pachycladus) - ripas; aroeira (Myracroduon urundeuva) moirões das cercas; angico (Anandenanthera colubrina) - marmeleiro (Croton blanchetianus) espécie principal utilizada ainda hoje na construção de cercas.

Além das espécies citadas anteriormente, há que ser destacado o uso das Cactáceas arbóreas como o facheiro (Pilosocereus pachycladus) e o mandacaru (Cereus jamacaru), e arbustivas como o xique-xique (Cereus gounellei), além da bromeliácea macambira (Bromélia laciniosa) como alimento pelo gado após serem queimados os seus espinhos, durante os períodos de secas prolongadas, prática ainda hoje existente, o que acarretou a rarefação e mesmo a extinção dessas espécies em diversos setores do Cariri.

Também como resultado do aumento da população, foi ampliado o extrativismo de diversas outras espécies para uso doméstico na forma de carvão vegetal e lenha, onde se destaca o consumo 
da madeira da jurema preta (Mimosa hostilis), preferida em relação às demais devido ao seu alto poder calorífico. Em períodos de estiagens prolongadas o corte dessa espécie pela população mais carente era intensificado, ampliando a produção de carvão para ser vendido na própria região, como uma fonte de obtenção de capital em épocas em que havia muita perda de gado pela fome ou sede.

\subsection{Domínio da cotonicultura:}

Apesar de todas as modificações efetuadas nas paisagens do Cariri em virtude do avanço da pecuária e da agricultura de subsistência nessa fase inicial, estendendo-se do final do século XVII à década de 1980, a cotonicultura conseguiu imprimir uma série de transformações nunca antes existente nessa região, o que ampliou consideravelmente as modificações na caatinga. Nesse caso, verifica-se que ao longo das várzeas ampliam-se as atividades agrícolas e, nesta fase, juntamente com a agricultura de subsistência, é introduzido o algodão. As demais áreas têm ainda nesse período as mesmas características de uso que o período anterior.

Planta de origem americana utilizada por vários povos indígenas, a partir da fase de colonização o algodão tem o seu uso inicial destinado à confecção de roupas rústicas pela população mais pobre e como alimento para o gado (torta-de-algodão).

A produção dessa fibra foi muito popular nessa região, ampliando-se principalmente a partir da Guerra de Secessão nos EUA (1861 a 1865), quando o mercado internacional, particularmente a Inglaterra, começou a incentivar a produção dessa importante matéria-prima industrial em diversas partes do mundo, uma vez que perdia temporariamente o seu grande centro produtor. Sendo plantado principalmente nos vales dos rios, nas áreas onde os solos não eram atingidos pelas enchentes periódicas, favoreceu ainda mais a retração da Caatinga Arbórea (Matas Ciliar) e da Caatinga Arbóreo-arbustiva Fechada originalmente existentes, através da retirada da vegetação pelo machado e/ou queimadas.

Nesse período, a necessidade de uma maior produção de fibras para o mercado trouxe algumas inovações para a cotonicultura, das quais destacamos a substituição do descaroçamento manual pelo uso de máquinas (bolandeiras), o que favoreceu ainda mais o aumento da área plantada com essa espécie. Como essa fase positiva para esse produto teve duração relativamente longa, áreas cada vez maiores foram desmatadas para o cultivo dessa espécie.

Já no início do século XX, uma das descrições mais interessantes sobre o quadro da vegetação do Cariri e do desmatamento a que foi e estava sendo submetido em virtude do avanço da cotonicultura foi realizada pelo botânico Philipp Von Luetzelburg, em alguns trabalhos de campo na Paraíba: 
Terminada as duas excursões parciaes, abandonei Alagoa do Monteiro...dirigindo-me para Cabaceiras. Segui primeiramente margeando o valle do riacho do Meio por estrada bem larga e transitada, que em virtude da vegetação débil da caatinga dava fácil passagem... Atravessando essa região tão secca, passamos por Volta e Queimação. A partir dali a vegetação se tornava de tal maneira pobre que toda a região parecia um deserto. Extensos trajectos de solo granítico e arenoso não mostravam vegetação a não ser pilosocereus setosus, ou uma ou outra opuntia a grandes intervallos; nada de árvores ou arbustos se notava...Já havíamos percorrido duas leguas atravez de tal deserto e avistamos apenas granito, areia e cactáceas (Xique-Xique); e o sol abrazador havia extinguido tudo na região monótona que parecia morta; um quadro desolador. [...] A tarde entrei em São Domingos, na margem esquerda do rio Parahiba, situado no sopé da serra de egual nome...Da historia dos colonisadores temos sciencia que o valle em tempos passados era cheio de bellas e extensas mattas virgens; hoje, porém, este valle está completamente arrasado de qualquer arvore, melhor ainda, pobre de toda e qualquer vegetação lenhosa. Em virtude das queimadas necessárias às culturas de algodão e à extracção de lenha para combustível, cada vez mais se accentua a devastação desordenada dos escassos restos de madeira ainda existentes nas caatingas; as construcções que surgem também concorrem, sobremodo, para a sua completa extincção.

Muito breve o sertão ficará privado de toda e qualquer madeira, ficando o estado na dura necessidade de importa-la dos estados visinhos. Uma caldeira comumente adoptada nos descaroçadores consome mensalmente de 20 a 30.000 achas de lenha, o que contribue para a devastação das mattas, como é de uso. (LUETZELBURG, 1922, p. 26-29).

Nesse trabalho, Luetzelburg (1922) também chama atenção para as partes mais secas e desprovidas de vegetação que ele encontrou no Cariri, as quais, segundo a sua avaliação, não se prestavam nem mesmo à pecuária, dada a esterilidade do terreno.

Também no início do século XX, Tavares (1909) destacava a carência de matas virgens no Cariri, assim como a presença de tabuleiros na região, particularmente na sua parte mais seca (oriental), onde ocorriam terrenos pedregosos e carentes de vegetação. Por essa razão, na visão do autor, seriam passíveis de aproveitamento somente para a pecuária.

A aridez dessa região, por sua vez, é destacada pelo agrônomo paraibano Lauro Pires Xavier, referindo-se as observações feitas pelo historiador conterrâneo Coriolano de Medeiros, em 1914, quando este último se reporta a sua vegetação: "Região central formada pelo platô da Borborema [...]. A região tem aspecto todo particular por sua vegetação composta quasi de cactáceas e bromeliáceas.” (apud XAVIER, 1942, p. 46). Aspecto ratificado por José Américo de Almeida, político e escritor paraibano de grande prestígio na década de 1920, sobre a mesma região: "A vegetação é rala e quase toda arbustea; mas nos sopés e nos vales se adensa [...]. Amiudam-se as favelas e as juremas." (ALMEIDA, 1994, p. 69).

Um pouco mais adiante, para o município de São João do Cariri (até a primeira metade do século XX com território bem maior que o atual), Lauro Pires Xavier fazia a seguinte observação:

A flora é monótona e triste. É a zona das cactáceas e bromeliáceas, onde há espaços em que se notam a fronde do umbuzeiro e da baraúna; por isso é mais apropriado à criação do gado. Chovendo, todos os campos se cobrem de excelentes forragens, faltando a chuva, apenas vicejam, como que desafiando os ardores do sol e aridez do terreno, o facheiro, a palmatória, o chique-chique, a coroa de frade, a cupeba, o mandacaru, a macambira, o carauá, o gravatá, etc. (XAVIER, 1942, p. 95). 
Para Andrade (1997), cujas observações se remontam a década de 1950, de todas as intervenções que provocaram alterações na vegetação do semiárido nordestino, coube a cotonicultura o papel decisivo para a degradação da flora originária dessas caatingas, o que permitiu, para este autor, a expansão de muitas espécies xerófitas à custa daquelas mais exigentes em umidade.

Dessa forma, a passagem do algodão por todo o Cariri, conforme já destacamos noutros momentos, dada a importância econômica, política e ecológica que exerceu principalmente a partir do século XIX, é fundamental para entendermos parte das modificações e também dos processos de degradação existentes nessa região, tanto direta como indiretamente.

Nesse contexto, com o avanço do algodão sobre muitas áreas de pastagem nativa, o gado teve de ocupar terras anteriormente pouco utilizadas, incorporando a essa atividade alguns tipos de solos que eram naturalmente mais restritivos a qualquer tipo de uso econômico, como os Planossolos. Logo, um tipo de caatinga ainda mais empobrecida em variedade e densidade de espécies passava a dominar algumas paisagens, iniciando-se assim a expansão das áreas com níveis mais elevados de desertificação.

Reiteramos que as queimadas para expansão da agricultura e renovação dos pastos modificaram substancialmente a caatinga, não apenas no Cariri, mas em todo o semiárido. Da mesma forma, a retirada da madeira para diversos fins (lenha, carvão vegetal, cercas e variados tipos de construções) teve efeito tão ou mais devastador. Além disso, como efeito indireto, entendemos que os danos à vegetação provocados pelo desmatamento tenham sido potencializados durante as fortes secas, uma vez que, já estando submetidas a elevado estresse hídrico, algumas espécies não resistiam ás modificações mais intensas.

Para exemplificar esse último caso, de 1845 a 1846, a Paraíba foi acometida por mais uma grande estiagem. Preocupado com a situação que se agravava cada vez mais, o governo provincial enviou uma comissão encarregada de indicar medidas e projetar obras para amenizar a situação. Diversas regiões foram visitadas, incluindo-se aí o Cariri. A comissão alertou que os sertanejos

[...] continuam a cortar e destruir matas, e árvores, nas proximidades dos açudes, rios e riachos! Se os agricultores e fazendeiros continuarem no estado de apatia a respeito dos açudes e celeiros e, se não plantarem constantemente árvores, ou não conservarem as que existem, nas proximidades dos rios, riachos e fontes, terão de abandonar a sua Província. (FERREIRA, 1993).

Joffily (1892) destacava que, apesar da secura climática do Cariri (denominado pelo autor de "caatinga"), as suas terras foram, num passado recente, mais férteis, uma vez que, como essa região havia sido intensivamente aproveitada para o plantio do algodão, as antigas matas presentes em seu 
território tinham sido devastadas e transformadas em vastos campos, próprios, segundo ele, apenas para a criação de gado.

Mais adiante, em outro trabalho, Joffily (1910) dá continuidade a essas denúncias em relação a erradicação de algumas das poucas áreas de matas ciliares ainda existentes no Cariri, num longo trecho de terras que se estendia dos municípios de São João do Cariri à Monteiro, mediante o avanço ainda maior da cultura do algodão.

Mesmo após o fim do ciclo de produção do algodão, as modificações causadas nos padrões de caatinga nessa região foram tão intensas que, em algumas áreas anteriormente ocupadas pela atividade agropecuária, a vegetação passou a enfrentar dificuldades maiores que as normais para estabelecer um processo de sucessão ecológica, muitas vezes não evoluindo ao longo do tempo, em quantidade e variedade de espécies., ainda que o uso das terras seja praticamente inexistente quanto às atividades econômicas diretas ou indiretas. As áreas que apresentam essa característica são denominadas ainda hoje pela população mais idosa da região como "terras cansadas". Um trabalho recente desenvolvido por Souza et al. (2015c) têm atribuído às altas temperaturas das camadas mais superficiais dos solos $(2 \mathrm{~cm}$ e $5 \mathrm{~cm})$ a razão desse processo de involução ecológica, em função do desmatamento acelerado pelo qual passaram algumas áreas do Cariri, uma vez que grande parte das sementes das espécies da caatinga não conseguem germinar em temperaturas que vem atingindo níveis superiores aos $35^{\circ} \mathrm{C}$ a essas profundidades por praticamente todo o ano. A expressão cartográfica dessa fase pode ser visualizada na figura 4.

A decadência da cotonicultura teve o seu maior impacto na década de 1980, em virtude da ocorrência da praga do bicudo (Anthonomus grandis) embora, na realidade, isto possa ser considerado a gota-d'água dessa queda da produção, visto que as razões principais para que isso ocorresse já vinham acontecendo desde a década de 1960: a competição com as fibras sintéticas e, ainda mais que isso, a falta de competitividade da produção paraibana (e, por extensão, de todo o Nordeste) frente as outras regiões brasileiras e de outros países (BARRETO et al., 2000). Embora na atualidade ainda seja característica a presença do algodão no Cariri, a sua produção se tornou bastante reduzida, estando muito mais relacionada ao seu aproveitamento tradicional como complemento alimentar para o gado que para a produção de fibra.

Devido a ligação secular que foi criada entre a produção algodoeira e a pecuária, a partir de 1960, através da crise da cotonicultura, observamos paralelamente, em alguns anos, também uma estagnação e mesmo declínio temporário da atividade criatória, particularmente dos bovinos, mais exigentes em alimentos que caprinos e ovinos, o que foi sentido em todo o semiárido nordestino.

Cabe ainda destacar a forte relação entre as questões anteriormente comentadas e a estrutura fundiária, do período inicial da colonização à estagnação da produção de algodão. Tradicionalmente, o conhecimento do produtor da diversidade florística e o seu aproveitamento 
diferenciado como alimento pelos tipos de gado, também funcionava como um trunfo para a sobrevivência do rebanho. Por exemplo, embora o marmeleiro (Croton blanchetianus) seja uma espécie bastante abundante nos pastos, como as suas folhas são tóxicas quando verdes, o seu consumo pelo gado só se dava no final da estiagem, após a sua queda, sendo aproveitadas principalmente pelos caprinos.

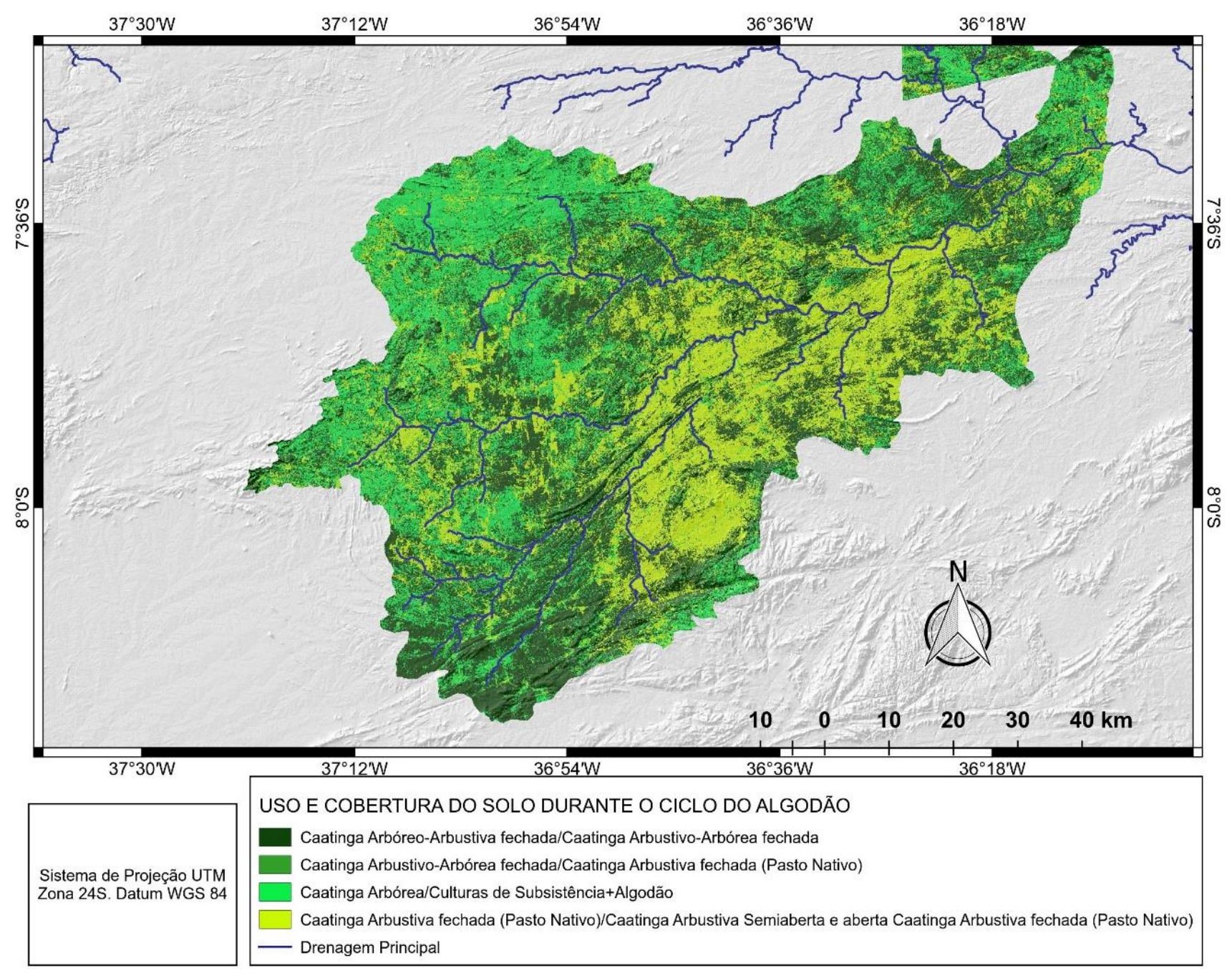

Figura 4 - Mapa do uso e cobertura dos solos no Cariri, durante o ciclo do algodão (final do século XVII à década de 1980).

Ainda nesse sistema, os bovinos alimentavam-se preferencialmente das gramíneas nativas e, à medida que essas iam escasseando, complementavam a sua dieta com as folhas de algumas árvores, especialmente de leguminosas como a catingueira (Poincianella gardneriana), além de consumirem a torta de algodão e também restos de folhas e caules dos alimentos produzidos na várzea (principalmente milho e feijão). Esse conhecimento permitia que os produtores, nos anos de chuvas mais regulares, deixassem o rebanho, ou parte dele, até seis meses nos pastos nativos (COHEN, 1997).

A estabilidade desse tipo de aproveitamento do solo se manteve durante vários anos em virtude da abundância de terras a serem utilizadas, existindo um período de pousio para as parcelas 
utilizadas que garantia, em geral, uma produtividade capaz de satisfazer as necessidades dos criadores em relação a sua subsistência e/ou a produção para o mercado.

Entretanto, a partir de séculos de repartições das propriedades por herança entre os familiares, a pressão sobre este meio foi ficando cada vez mais elevada, já que passou a ocorrer a diminuição do tempo de pousio das terras, o que acarretou numa maior intensificação do uso dos solos e da vegetação nativa. Além disso, o grande número de pequenas propriedades resultante desse processo também tornou mais difícil, pela exigüidade de terras disponíveis, a aplicação de algumas tecnologias tradicionais de convivência com o semiárido.

\subsection{Fase atual:}

A partir da década de 1970, pressões políticas internas e questões relacionadas ao mercado internacional de carne fizeram com que no Brasil a pecuária passasse a receber uma série de benefícios oriundos de diversos programas governamentais. Para esse setor, apesar da sua tradição no semiárido, os incentivos governamentais que passaram a ocorrer, pela maneira como se desenvolveram nas áreas de caatinga, acabaram contribuindo fortemente para a ampliação da sua degradação.

No contexto acima descrito, apesar de serem inicialmente dominantes no Cariri, os bovinos foram aos poucos substituídos pelos caprinos. No final do século XIX, Joffily (1892) já chamava atenção para o fato desses animais estarem adquirindo uma importância cada vez maior nas propriedades do semiárido paraibano. Isto se devia ao preço elevado que atingia suas peles no mercado, além de sustentarem o sertanejo com carne e leite, já que este encontrava cada vez mais dificuldades para criar o gado bovino.

As dificuldades anteriormente mencionadas em relação a criação dos bovinos, em princípio, poderiam ser atribuídas a sua menor resistência às secas, quando comparado aos caprinos e até mesmo aos ovinos. Embora não neguemos essa questão, baseado no que levantamos nesse trabalho, um exame mais apurado dessas razões nos leva a explicar esse problema também em função da diminuição dos tamanhos das propriedades e a conseqüente menor disponibilidade de pasto nativo, conforme já destacamos noutro momento.

Esses fatos, juntamente com a declaração da inexistência de preocupação em relação a capacidade de carga da vegetação da caatinga podem ser identificados em Joffily (1892) como os primeiros registros dos efeitos da desertificação provocados pelo pastoreio na história da Paraíba.

Corroborando as nossas idéias, Almeida (1994) destaca que, no início do século XX, no semiárido paraibano, particularmente nas ribeiras mais secas e outros tipos de terrenos, nos maiores 
intervalos das estiagens, os rebanhos multiplicavam-se. Em conseqüência, com o aumento da exploração da vegetação, junto com os efeitos das secas, a raça bovina foi degenerando.

Referindo-se aos caprinos, Almeida (1994) destaca a sua rusticidade. Ressalta que pouco lhe importava a seca, apresentando capacidade de sobreviver onde qualquer outro tipo de gado morreria de fome, como nas estepes da Ásia e da África. Denomina o Cariri de "paraíso das cabras", devido ao rebanho de 170.412 cabeças (dados de 1915), ao mesmo tempo em que ressalta o papel de artífices dos desertos desses animais, por conta das suas características alimentares.

Esse papel de artífices dos desertos envolve não apenas as características intrínsecas dos caprinos e o seu número, mas também a forma como eram e ainda hoje, em geral, são criados. Nesse sentido, Grabois ; Aguiar (1984) destacam que, no Cariri, o que também pode ser considerado uma regra para quase todo o semiárido paraibano e nordestino, quando o algodão era uma cultura mais difundida, o gado bovino se utilizava do pasto nativo a maior parte do ano. Por volta de novembro/dezembro, quando se concluía a sua colheita, devido a diminuição do pasto (em virtude da seca) e das grandes exigências em alimento dos bovinos, estes eram postos para se alimentar do restolho dessa planta e de outros cultivos, até março, quando era iniciado o período chuvoso na região.

Quanto aos caprinos, os autores destacam que estes permaneciam, juntamente com as ovelhas, nas pastagens nativas durante o ano inteiro, só recebendo alimentação complementar nos casos de estiagens muito prolongadas.

Embora esses animais sejam principalmente ramoneadores, o que faz com que prefiram folhas de plantas arbustivas e arbóreas às herbáceas, dependendo dos tipos de caatinga ocupadas pelo rebanho, o estrato herbáceo também pode contribuir significativamente em sua dieta (SOARES et al., 2006). Sua capacidade de se aproveitar de diversos tipos de plantas é muito grande, chegando a se alimentar de até 70\% das espécies existentes na caatinga (ARAÚJO FILHO et al., 1996, 1999a, 1999b).

Sobre a pressão dos caprinos sobre a caatinga, Albuquerque et al. (2003), submetendo uma pastagem nativa no semiárido pernambucano a várias intensidades de usos por esses animais, constataram que altas taxas de uso por caprinos (1 cabra/1ha.), durante três anos, por si só, não foram suficientes para causar diferença na freqüência das espécies herbáceas nem na densidade das plantas novas das espécies lenhosas, não ocorrendo degradação do estrato herbáceo. Entretanto, foi observado que a degradação da vegetação ocorreu quando as altas taxas de lotação estiveram associadas a ocorrência de estiagens prolongadas, o que é comum para todo o semiárido, principalmente quando ocorre o fenômeno El Niño.

Ainda em relação a herbivoria dos caprinos em áreas de caatinga, um importante trabalho foi desenvolvido por Leal et al. (2005) em parte do semiárido pernambucano (região de Xingó). Essa 
pesquisa constatou que esses animais constituem importante fator de seleção natural, afetando principalmente arbustos e árvores perenifólias, como o juazeiro (Ziziphus joazeiro) e o umbuzeiro (Spondias tuberosa), ou espécies decíduas com ciclo reprodutivo parcial ou completo na estação seca, como a aroeira (Myracroduon urundeuva) e a imburana (Commiphora leptophoeos).

Todas as espécies mencionadas são clímax nas paisagens da caatinga. A diminuição dos seus números, mediante a ação dos caprinos, ocorre em função de estarem acessíveis ao pastoreio na época em que estes animais dependem exclusivamente da vegetação lenhosa para se alimentarem. Além disso, no consumo de alguns frutos nativos, algumas sementes são totalmente trituradas, impedindo-se assim a sua reprodução.

Esses estudos comprovam que altas taxas de lotação de caprinos em áreas de caatinga, quando associadas a outras formas de pressão sobre a vegetação, têm o poder de empobrecer e reduzir o porte das plantas, levando à ocorrência de desertificação, o que também já foi constatado em outras regiões semiáridas fora do Brasil (LEAL et al., 2005).

Quanto ao crescimento recente da pecuária no Cariri e dos seus efeitos na cobertura vegetal do Cariri, com repercussões intensificadas a partir de 1980, este também deve ser entendido não somente pela menor dependência dessa atividade à presença de água e alimentos, mas principalmente em função da demanda do mercado por carne, onde o Estado passa a exercer um papel fundamental. A título de exemplo, Duque (1984/1985) destaca que, para todo o Nordeste, entre 1971 e 1977, aproximadamente a metade do crédito total do Programa de Redistribuição de Terras e de Estímulo à Agroindústria do Norte e Nordeste (PROTERRA) foi dedicado à pecuária.

A participação da SUDENE nesse processo também foi importante. Ocorreu particularmente através do Projeto Sertanejo (1976-1983), contando com o apoio financeiro do Banco Mundial (BIRD) e do Banco Interamericano de Desenvolvimento (BID), tendo a pecuária monopolizado grande parte dos recursos financeiros, conforme observado por Moreira ; ; Targino (1997).

Os subsídios ao setor pecuário ainda hoje têm continuidade, inclusive para os pequenos produtores. No Cariri, essas ações são direcionadas às associações de criadores de caprinos, estimulando a aquisição de animais com maior capacidade de produção leiteira e de carne. Nesse caso, a diminuição do tamanho das propriedades, associada aos incentivos à pecuária e as transformações na agricultura do Cariri, provocaram forte aumento de pressão sobre as pastagens nativas, o que foi acentuado ainda mais recentemente pelo fato de, a partir de 2011, uma forte estiagem, associada a ocorrência da praga da cochonilha (Dactylopius coccus) ter dizimado quase por completo as plantações de palma-forrageira (Opuntia fícus indica), Cactácea exótica utilizada como principal forrageira cultivada na região, obrigando muitos criadores a retornarem ao uso de Cactáceas nativas para alimentar o gado. 
Também relativo a esse período mais recente e fortemente relacionado à pecuária, temos a introdução da algaroba (Prosopis juliflora) no Cariri. Essa espécie, originária da região desértica de Piura (Peru), foi introduzida no Brasil a partir de 1942, com o objetivo de tornar a pecuária do semiárido menos dependente das pastagens nativas. Enquanto as pastagens nativas, em sua maioria, apresentam produção forrageira, embora abundante, restrita à curta estação chuvosa, a algaroba (Prosopis juliflora), além da resistência à seca, é perene, sendo as suas folhagens e sementes apreciadas pelo gado. Adiciona-se a essas características, o fato de frutificar no período de estiagem, quando são escassos os estoques naturais de alimento para os animais.

A partir da década de 1970, o governo federal começou a oferecer apoio financeiro a fundo perdido para os produtores que enviassem projetos de reflorestamento com essa espécie, através do antigo Instituto Brasileiro de Desenvolvimento Florestal (IBDF, incorporado atualmente ao Instituto Brasileiro de Meio Ambiente e Recursos Naturais Renováveis - IBAMA) e da SUDENE.

Na Paraíba, essa atividade iniciou-se em 1979, prolongando-se até 1986 (PARAÍBA, 1994) e, já em 1980, o Cariri paraibano concentrava 83\% da produção estadual dessa planta (MOREIRA ; TARGINO, 1997). Ainda nesse período, Castro (1986) destaca que até outubro de 1983, 80 projetos de reflorestamento com essa espécie tinham sido aprovados no Cariri, numa área total de 12.870ha., distribuída por 5.469 propriedades. Mesmo com o fim do financiamento, a expansão dessa espécie para muitas áreas, particularmente as várzeas dos rios, passou a ocorrer de forma espontânea, com as sementes trazidas pelas águas das chuvas ou diretamente através do gado que consome as suas vagens, substituindo quase toda antiga Mata Ciliar composta de espécies nativas.

De forma resumida, essa fase de uso e ocupação das terras do Cariri, notadamente a partir da década de 1980, através das Políticas Públicas que ocorreram na região, vem se caracterizando pelo retorno da pecuária como a atividade econômica dominante na região. Nesse caso, um novo processo de retração e modificação dos padrões de caatinga tem início, não apenas pelo aumento do rebanho e da sua pressão sobre a vegetação nativa. É também resultante da introdução de plantas exóticas que podiam ser utilizadas como alimento pelo gado, destacando-se, nesse processo, a algaroba (Prosopis juliflora), passando esta a ocupar espaços anteriormente dominados pelos diversos tipos de caatinga ou aquelas áreas onde se praticava a cotonicultura, em especial as áreas de Caatinga Arbórea (Mata Ciliar).

No Cariri, em relação à pecuária, destacou-se a caprinocultura, pelas diversas vantagens frente aos bovinos e os incentivos governamentais que começaram a acontecer a partir da década de 1970, conforme já destacamos anteriormente. Paralelo ao crescimento desse rebanho, ocorre uma importante contribuição desenvolvida através dessa atividade ao processo de desertificação que já vinha acontecendo na região. Os hábitos alimentares desses animais e principalmente a forma semiextensiva como os mesmos são criados, fazem com que estes se tornem, na maior parte dos 
casos, totalmente dependentes da alimentação fornecida pela vegetação nativa. Isto, associado ao fato de não existir nenhum tipo de manejo nos pastos nativos, transforma a herbivoria numa característica comum nessas terras.

Nesse caso, durante a estação seca, quando a biomassa diminui e, em consequiência disso, ocorre menor oferta de alimento para o gado, passa a existir um impacto que também atinge os caprinos, relacionado a queda na produção leiteira e de carne, além de, muitas vezes, se a estiagem for mais prolongada que o normal, haver a morte parcial do rebanho.

Esse processo acaba fazendo parte de um ciclo vicioso, pois durante o retorno da estação chuvosa, os produtores irão substituir os animais perdidos durante a última estiagem, procurando recuperar o prejuízo e, se possível, aumentar ainda mais o rebanho. Dessa forma, as paisagens vão sendo dominadas por uma vegetação cada vez menos diversificada e com pequena densidade, onde a presença de solos quase completamente desnudos, mesmo durante a estação chuvosa, passa a ser um elemento marcante em diversas áreas dessa região. A figura 5, a seguir, expressa esse momento.

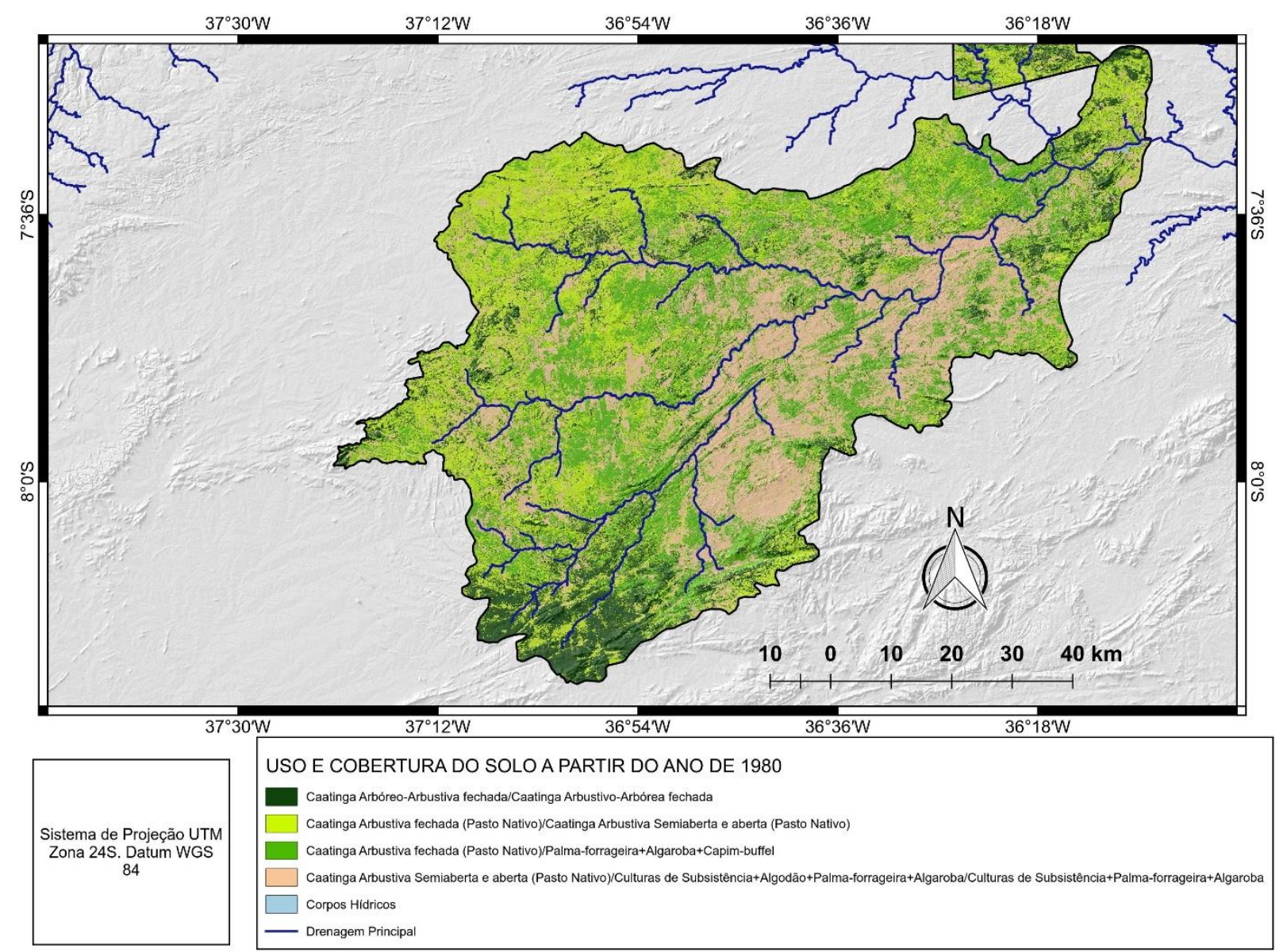

Figura 5- Mapa do uso e cobertura dos solos no Cariri, a partir dos anos 1980.

Nessa nova fase, ao longo dos rios o uso dos solos se dá de forma mais intensa, representado pelas culturas de subsistência e ainda parcialmente pelo algodão, sendo que, nesse último caso, essa fibra vegetal passa a dividir espaço ou mesmo cedendo-o por completo à algaroba (Prosopis 
juliflora) e à palma forrageira (Opuntia ficus indica), ainda que esta última espécie esteja momentaneamente em retração.

Nas áreas adjacentes às várzeas, verifica-se a substituição mais expressiva que nos períodos anteriores da Caatinga Arbóreo-arbustiva Fechada e Arbustiva Fechada pela Caatinga Arbustiva Semiaberta e Aberta, passando a compor áreas desertificadas, permanecendo a Caatinga Arbustivoarbórea Fechada e a Caatinga Arbustiva Fechada nos solos do tipo Luvissolo Crômico e Neossolo Litólico, com muito das suas características originais preservadas em áreas de topografia acidentada, como pode ser visualizado no perfil da figura 6 .

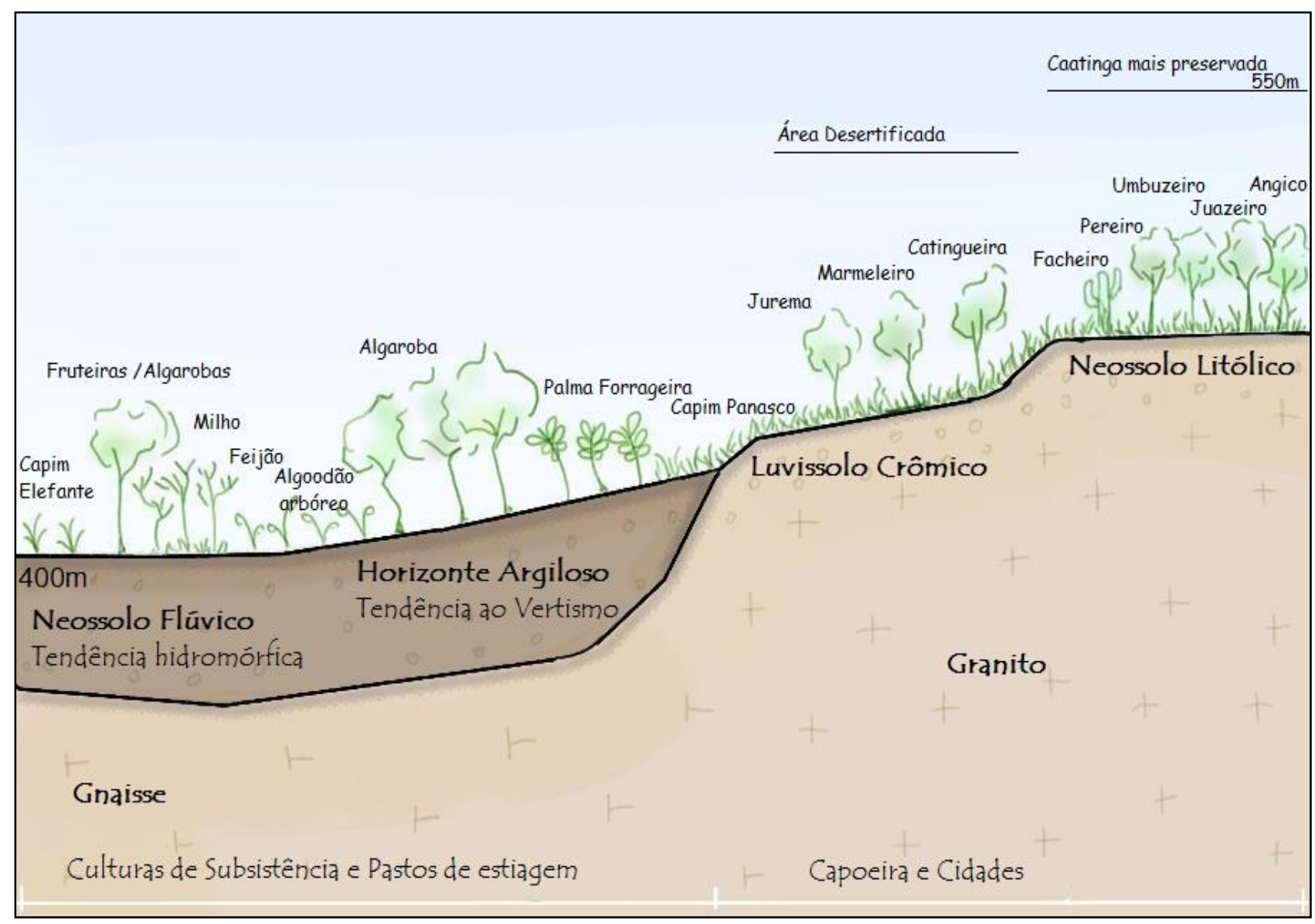

Figura 6 - Perfil de uso e cobertura vegetal atual na região dos Cariris Velhos, destacando as espécies mais representativas.

Fonte: Elaborado pelos autores.

\section{CONSIDERAÇÕES FINAIS}

Esse artigo demonstra uma relação direta do uso e ocupação histórica das terras do Cariri paraibano com as paisagens vegetais encontradas atualmente na região, inclusive fornecendo informações fundamentais para se entender como foram originadas algumas áreas consideradas desertificadas na região. Nesse caso, para muito além de uma dinâmica natural, temos um exemplo claro de uma Natureza não apenas incorporada, mas recriada pelo Homem. 
No contexto anteriormente apresentado, percebemos que as poucas áreas onde ainda temos uma caatinga melhor preservada, estaria localizada em áreas marginais do ponto de vista do aproveitamento direto dos recursos naturais, como afloramentos rochosos, serras e áreas com solos com problemas de salinização. Ainda assim, os dados levantados permitiram que se identificasse uma diminuição acentuada da vegetação nativa, em quantidade e diversidade, construindo uma nova dinâmica onde domina a degradação e um panorama futuro incerto para essas terras, levando em consideração o pouco conhecimento científico que ainda temos sobre a caatinga, estabelecendo-se uma situação ainda mais complexa e difícil de decifrar quando vários dos processos naturais vigentes originalmente foram amplamente transformados pelo Homem.

Como se trata de um quadro mutável a qualquer momento, tanto as áreas de uso econômico mais intenso como as que estão desertificadas e as que ainda apresentam um quadro vegetal mais preservado podem sofrer algum tipo de modificação, a exemplo da chegada das águas da transposição do rio São Francisco, que em seu Eixo Leste atravessará essa região, o que fatalmente acarretará um incremento ao desenvolvimento de projetos de agricultura irrigada, inclusive incorporando nesse processo áreas com solos naturalmente salinizados e correndo o risco de agravar esse problema nessas terras, entre outras possibilidades.

Ao mesmo tempo, o tipo de análise feita com base nos procedimentos metodológicos utilizados nesse trabalho pode ser aperfeiçoado, agregando valor ao que foi desenvolvido, incorporando outras técnicas ainda pouco usuais em Geografia, como é o caso das análises polínicas e cronológicas, datando e investigando material sedimentar dos últimos 500 anos, quando partimos de um período anterior a chegada do colonizador europeu até os dias atuais, o que abriria a possibilidade de descobrir marcas do passado recente até o presente, para explicar ainda mais as paisagens que temos agora. Portanto, temos um quadro inicial de descobertas que abrem espaço para novas indagações e possibilidades.

\section{AGRADECIMENTOS:}

Os autores agradecem o apoio financeiro do Ministério do Meio Ambiente/Fundo Nacional sobre Mudança do Clima ao projeto 02/2014 "Desenvolvimento de capacidades técnicas e institucionais de parceiros locais em bacias hidrográficas para o desenvolvimento de estratégias para a conservação de ambientes naturais: Conhecendo as relações biofísicas e antrópicas para subsidiar uma convivência sustentável no Alto Curso do rio Paraíba - PB” que permitiu a realização deste trabalho. 


\section{REFERÊNCIAS}

AGUIAR, W. ; RIBEIRO COUTINHO, M. O. Elias Herckmans. Descrição Geral da Capitania da Paraíba. João Pessoa: A União, 1982, 60 p.

ALBUQUERQUE, E. S.; CANDIOTTO, L. Z. P.; CARRIJO, B. R.; MONASTIRSKY, L. B. A nova natureza do mundo e a necessidade de uma biogeografia "social". Geosul, Florianópolis, v. 19, n. 38, p. $141-158$, jul - dez. 2004.

AlbuQuerque, S. G.; SOARES, J. G. G.; GUIMARÃeS FILHO, C.; OLIVEIRA, M. C. Dinâmica do estrato herbáceo de uma vegetação de caatinga do sertão pernambucano, sob intensidades de uso por caprinos. Petrolina: Embrapa, 2004. Disponível em <www.cpatsa.embrapa.br>. Acesso em: 04 jan. 2007.

ALMEIDA, E. História de Campina Grande. $2^{\mathrm{a}}$ ed. João Pessoa: Ed. Universitária da UFPB, $1979,235 \mathrm{p}$.

ALMEIDA, J. A. A Paraíba e seus problemas. $4^{\text {a }}$ ed. Brasília: Senado Federal/Fundação Casa de José Américo, 1994, 356 p.

ANDRADE, G. O. O rio Paraíba do Norte. João Pessoa: Ed. Universitária da UFPB/Conselho Estadual de Cultura, 1997, 178 p.

ANDRADE, L. A.; PEREIRA, I. M.; LEITE, U. T.; BARBOSA, M. R. V. Análise da cobertura de duas fitofisionomias de caatinga, com diferentes históricos de uso, no município de São João do Cariri, Estado da Paraíba. Cerne, Lavras, v. 11, nº 3, p. 253 - 262, jul/set. 2005.

ANDRADE-LIMA, D. The caatingas dominium. Revista Brasileira de Botânica, São Paulo, v. 4, v. 4, p. 149-153, 1981.

ARAÚJO FILHO, J. A.; BARBOSA, T. M. L.; CARVALHO, F. C. Sistema de produção silvopastoril para o semi-árido nordestino. Boletim da Embrapa, Sobral, 29: 1-2, 1999a.

ARAÚJO FilHO, J. A.; BARBOSA, T. M. L; CARVAlHO, F. C.; CAVAlCANTI, A. C. R. Sistema de produção agrossilvopastoril para o semi-árido nordestino. Boletim da Embrapa, Sobral, 30: 1-2, $1999 b$.

ARAÚJO FILHO, J. A.; GADELHA, E. R.; LEITE, P. Z.; SOUZA, S. M. A.; CRISPIM, M. C. R. Composição botânica e química da dieta de ovinos e caprinos em pastoreio combinado na região dos Inhamuns, Ceará. Revista da Sociedade Brasileira de Zootecnia, Viçosa: UFV, 25: 383-395, 1996.

ARrudA MEllo, J. O. História da Paraíba. $7^{\text {a }}$ ed. João Pessoa: A União, 2002, 226 p.

BARBOSA, D. C. A.; ALVES, J. L. H.; PRAZERES, S. M.; PAIVA, A. M. A. Dados fenológicos de 10 espécies arbóreas de uma área de caatinga (Alagoinha - PE). Acta Botânica Brasílica, 3: 109-117, 1989.

BARRETO, A.; EVANGELISTA, M. L.M.; SOUZA, H. F. Recuperação da cultura do algodão. João Pessoa: SEBRAE-Pb, 2000, 276 p.

BERNARDES, N. As caatingas. Revista de Estudos Avançados. Dossiê Nordeste seco. 13 (36), São Paulo: Centro de Estudos Avançados, p. 69-78, 1999. 
CÁMARA, R. e DÍAZ DEL OLMO, F. Directrices y Gestión para la Conservación y Desarrollo Integral de un Humedal Centroamericano: Golfo de Montijo (Litoral del Pacífico, Panamá). Panamá: Embajada de España en Panamá, 2004, 311p.

COHEN, M. As práticas sócio-ecológicas frente à seca: limites e contradições no exemplo do Cariri paraibano. CASTRO, E. ; PINTON, F. (Orgs.). Faces do Trópico Úmido. Conceitos e questões sobre desenvolvimento e meio ambiente. Belém: CEJUEP/NAEA/UFPA, p. 399-4520, 1997.

DE MARTONNE, E. Traité de Géographie Phsysique. Paris: Armand Colin, v. III, 1932, 576 p.

EITEN, G. An outline of the vegetation of South America. Symposia of the $5^{\text {th }}$ Congress of the International Primatological Society. Nagoya, p. 529-545, 1974.

Classificação da vegetação do Brasil. Brasília: CNPq, 1983, 234 p.

ELHAI, H. Biogéographie. Paris: Librairie Armand Colin, 1968, 354 p.

FERREIRA, L. F. G. Raízes da indústria da seca. O caso da Paraíba. João Pessoa: Ed. Universitária da UFPB, 1993, 152 p.

FIGUEIRÓ, A. Biogeografia: dinâmicas e transformações da natureza. São Paulo: Oficina de Textos, 2015, 384 p.

FONT I QUER, P. La végétation, Géografía de España Y Portugal. Terán y col. (edits.). Barcelona: Edit. Montaner y Simón, 1954, v. III, p. 145 - 271.

FURLAN, S. A.; SOUSA, R. M.; LIMA, E. R. V.; SOUZA, B. I. Biogeografia: reflexões sobre temas e conceitos. Revista da ANPEGE, v. 12, n. 18, p. 97 - 115, Especial GT ANPEGE 2016.

GARCÍA FERNANDEZ, J. Geografía Física o Ciencias Naturales. Investigaciones Geográficas, n. 25 , p. $33-49,2001$.

GRABOIS, J. ; AGUIAR, M. J. N. O Cariri paraibano: um estudo de geografia agrária regional primeira aproximação. Ciência e Cultura, 37 (12), Rio de Janeiro: SBPC, p. 1965-1986, dez. 1985.

JOFFILY, I. Notas sobre a Parahyba. Rio de Janeiro: Typographia do Jornal do Commercio, $1892,276 \mathrm{p}$.

. Notas de viagem da villa de São João do Cariri a do Monteiro. Revista do Instituto Histórico e Geographico Parahybano, ano II, v. 02. Parahyba: Imprensa Oficial, 1910.

LEAL, J. Vale de Travessia. 2a ed. Campina Grande: Editora e Gráfica Santa Fé, 1993, 187 p.

LEAL, I. R.; VICENTE, A.; TABARELLI, M. Herbivoria por caprinos na caatinga da região de Xingó: uma análise preliminar. LEAL, I. R. ; SILVA, J. M. C. (Edit.). Ecologia e conservação da caatinga. Recife: Ed. Universitária/UFPE, 2005, p. 695-715.

LUETZELBURG, P. V. Estudo botânico do Nordeste. $2^{\text {a }}$ ed. Rio de Janeiro: Ministério da Viação e Obras Públicas/IFOCS, v. 2, 1922, 226 p.

MCNEELY, J. A. Aprender com o passado: florestas e biodiversidade. Tradução: NEIL BECK. Revista Florestal, vol. XI, n. 1, jan. - jun. 1998, p. 38 - 52. 
MEAZA, G. Perspectivas de investigación en Biogeografía. IN: III ENCUENTRO DE GEOGRAFÍA CATALUNYA - EUSKAL HERRIA. Barcelona: Edit. Universidad de Barcelona Sociedad Catalana de Geografía, 1993, p. 293 - 310.

MELlO NETO, J. A. G. Manuel Arruda Câmara: obras reunidas. Recife: Fundação de Cultura da Cidade do Recife, 1982, 377 p.

MOREIRA, E. ; TARginO, I. Capítulos de Geografia Agrária da Paraíba. João Pessoa: Ed. Universitária da UFPB, 1997225 p.

NANTES, M. Relação de uma missão no rio São Francisco. Tradução e comentários Barbosa Lima Sobrinho. $2^{a}$ ed. São Paulo: Companhia Editora Nacional, Coleção Brasiliana, v. 368, 1979, $133 \mathrm{p}$.

PEGADO, C. M. A. Efeitos da invasão da algaroba (Prosopis juliflora sw D.C) sobre a composição florística e a estrutura da caatinga no município de Monteiro-Paraíba. 2004. 106 f. Dissertação de Mestrado (Agronomia), - Programa de Pós-Graduação em Agronomia, UFPB, Areia, 2004.

PINTO, I. F. Datas e notas para a História da Paraíba. V. 1. João Pessoa: Ed. Universitária da UFPB, 1977, $337 \mathrm{p}$.

QUINTANILLA, V. G. Sobre los fundamentos y princípios de la Biogeografía. Boletim de Estudos Geográficos, v. 20, n. 78, p. 56 - 70, 1981.

RIZZINI, C. T. Nota prévia sobre a divisão fitogeográfica do Brasil. Revista Brasileira de Geografia, 25: 3-64, Rio de Janeiro: IBGE, 1963.

SAMPAIO, E. V. S. B.; SALCEDO, I. H. Effect of different fire severities on coppicing of caatinga vegetation in Serra Talhada, PE, Brazil. Biotropica, 25: 452-460, 1993.

SAMPAIO, E. V. S. B.; ARAÚJO, E. L.; SALCEDO, I. H.; TIESSEN, H. Regeneração da vegetação de caatinga após corte e queima em Serra Talhada, PE. Pesquisa Agropecuária Brasileira, 33: 621-632, 1998.

SANTOS, M. Técnica espaço tempo: globalização e meio técnico-científico-informacional. São Paulo: Hucitec, 1997, 337 p.

SIMMONS, I. G. Biogeografia: natural y cultural. Barcelona: Omega, 1982, 354 p.

SOUZA, B. I. Cariri Paraibano: do silêncio do lugar à desertificação. 2008. 198f. Tese (Doutorado em Geografia), UFRGS, Porto Alegre, 2008.

SOUZA, B. I. ARTIGAS, R. C.; LIMA, E. R. V. Caatinga e desertificação. Mercator, v. 14, n. 1, p. $131-150,2015$.

SOUZA, B. I.; MACÊDO, M. L. S.; SILVA, G. J. F. Temperatura dos solos e suas influências na regeneração natural da caatinga nos Cariris Velhos - PB. Ra'ega, v. 35, p. 261 - 287, dez. 2015.

SOUZA, B. I.; QUEIROZ, R. T.; CARDOSO, E. C. M. Degradação e riscos à desertificação no Alto Curso do rio Paraíba - PB, Brasil. Revista da ANPEGE, v. 11, n. 16, p. 201 - 222, jul - dez. 2015. 
SUERTEGARAY, D. M. A. Pesquisa de campo em Geografia. Geographia, vol. 4, n. 7, p. 64 - 68, 2002.

TAVARES, J. L. A Parahyba. Vol 02. Parahyba: Imprensa Oficial, 1909, 233 p.

VELASCO, J. C. G. La acción humana, el paisaje vegetal y el estúdio biogeográfico. Boletim de la Associación de los Geógrafos de Espanã, n. 31, p. 47 - 60, 2001.

VELOSO, H. P. ; GÓES-FILHO, L. Fitogeografia brasileira. Classificação fisionômica-ecológica da vegetação Neotropical. Projeto RADAMBRASIL, Boletim Técnico, Série Vegetação 1: 1-79. Rio de Janeiro: Ministério das Minas e Energia, 1982.

XAVIER, L. P. O caroá. História, cultura e distribuição geográfica. Rio de Janeiro: Ministério da Agricultura, 1942, 225 p.

Trabalho enviado em 02/11/2016

Trabalho aceito em 05/12/2016 